\title{
Utilization of Village Potential for the Development of Village Business Company (VBC) Entities in North Sumatera, Indonesia
}

\author{
Badaruddin $^{1 *}$, Kariono $^{2}$, Bisru Hafi ${ }^{3}$ \\ 1, 2, 3 Universitas Sumatera Utara, Medan, Indonesia \\ Email: badaruddin@usu.ac.id
}

\begin{abstract}
Inequality of rural development compared to urban development has become common place in Indonesia. Various policies and programs have been carried out by the government to reduce this inequality. Village Autonomy through Law Number 6 of 2014 concerning Villages is a major breakthrough made by the government to overcome this inequality. The establishment of Village Business Company (VBC) as mandated in the Village Law is one that is considered capable of being a solution for accelerating economic and social development in the village. VBC is expected to be able to explore and utilize all the potential of the village to be utilized in empowering and improving the welfare of rural communities. The purpose of this study is to analyze the utilization of village potential in the development of $\mathrm{VBC}$ for the progress of village development. The research design used in this study is a combination of qualitative and quantitative approaches with a dominant-less dominant model, where the qualitative approach is used as the dominant approach, while the quantitative approach is the less dominant. The number of respondents in this study was 300 people, while the informants consisted of village government, VBC managers, VBC partners, and community leaders. The study was conducted on $3 \mathrm{VBC}$ in 3 villages located in 3 regencies in North Sumatera Province. The results showed that most of the respondents (66.7\%) stated that VBC managers had optimally utilized the village's potential in developing VBC in their villages. VBC managers have utilized existing human resources in the village to be involved in the management of VBC, especially human resources from young people. In addition to the potential of human resources, VBC managers have also utilized the potential of the village's natural resources for business activities and for improving welfare, both economic welfare and increasing the quality of services received by villagers, such as providing clean water services for household needs, and financial transactions through BRI-Link services. The ability of VBC managers to take advantage of village potential and the ability to build networks with various parties is a strategy that must be carried out by managers so that $\mathrm{VBC}$ can develop. The support of various parties, especially the village government and district, provincial and central governments is the key to the success of $\mathrm{VBC}$ as the locomotive of development in the village.
\end{abstract}

Keywords: Village Business Company, Village Potential, Community Welfare, Development Village

\section{INTRODUCTION}

Inequality in rural-urban development has become commonplace in Indonesia. Various policies and programs have been carried out by the government to reduce this inequality. Village Autonomy through Law Number 6 of 2014 concerning Villages is a major breakthrough made by the government to overcome this inequality. The establishment of Village Business Company (VBC) as mandated in the Village Law is one that is considered capable of being a solution for accelerating economic and social development in the village. VBC is expected to be able to explore and utilize all the potential of the village to be utilized in empowering and improving the welfare of rural communities.
Village Business Company (VBC) are an alternative to village socio-economic institutions that are considered capable of being a locomotive in the utilization of all potential resources in the village (Natural Resources and Human Resources). The acceleration of rural development through VBC is expected to reduce inequality in rural-urban development.

The results of research Badaruddin, et al. [1] found that Village Business Company can improve the welfare of rural communities if VBC are managed properly. One way to manage Village Business Company well is to utilize social capital. Research Results Badaruddin, et al. [2] concluded that the village actually has a variety of potential social capital that can be utilized in the context implementing 
Law no. 6 of 2014 concerning Villages which can be grouped into two forms of potential social capital, namely: first, potential social capital in the form of value; and second, the potential for social capital in the form of institutions (formal and non-formal institutions).

The problem is, not all Village Business Company are able to explore the potential of the existing village, and have not been able to utilize the potential of the village as a business unit that can contribute to improving the village economy. Ideally, Village Business Company should be able to recognize and explore the potential of the village and be able to also take advantage of it as a new economic opportunity and source for the village community. If this can be done by Village Business Company, then job opportunities for rural communities will be more open. This study aims to analyze the utilization of village potential in the development of VBC for the progress of village development.

\section{LITERATUR REVIEW}

Village development is essentially aimed at producing the welfare of the village community. To achieve this goal, various policies and programs are made by the government. Village development policies and programs will only succeed if the village government and village communities are able to explore the various local potentials of the village. Soetomo [3] mentions that there are 3 things that need to be considered in identifying local potential, namely, 1) identifying community needs which from time to time always experience developments and changes in line with changes and community developments; 2) Identification of potential, resources and opportunities that are also always developing. Without these activities, the existing potential and resources will remain latent and not actualized to fulfill needs; and 3) Processes and efforts to find more profitable ways to utilize existing potential and resources.

The ability to explore the potential of the village (local) is one of the prerequisites for the success of village development. The same thing is also found in the development of Village Business Company. According to research results Danaresa, et al. [4], Badaruddin, et al. [5], Kurniasih, et al. [6], Iyan, et al. [7] shows that the ability to utilize village potential is a determining factor for the success of VBC development. The potential of the village in question can be in the form of potential natural resources (springs which are important village assets), potential human resources (positive support from residents, social capital, and community participation).

\section{RESEARCH METHOD}

The research design used in this study is a combination of qualitative and quantitative approaches with a dominant-less dominant model, where the qualitative approach is used as the dominant approach, while the quantitative approach is the less dominant. The number of respondents in this study was 300 respondents, while the informants consisted of the village government, managers of Village Business Company, Business Partners of Village Business Company, and community leaders. The study was conducted on 3 Village Business Company in 3 villages located in 3 districts in North Sumatera Province. The Village Business Company used as research subjects are Village Business Company Arih Ersada in Raya Village, Berastagi District, Karo Regency; Village Business Company by the Village of Buluh Duri Mandiri, Sipis-Pis District, Serdang Bedagai Regency; and Village Business Company by Subur Makmur Village, Air Joman District, Asahan Regency.

\section{RESEARCH RESULTS AND DISCUSSION}

In managing and developing $\mathrm{VBC}$, measurable and systematic efforts and strategies are needed to achieve goals. These strategies and efforts include the utilization of the potential possessed by the village, both the potential for natural resources and the potential for human resources. Table 4.1. shows how the respondent's view of the VBC manager is related to the utilization of the village's potential.

Tabel 4.1. VBC Managers have Utilized Village Potential in Business Development

\begin{tabular}{|c|c|c|c|c|c|c|c|c|}
\hline \multirow{3}{*}{ Perception } & \multicolumn{6}{|c|}{ VBC } & \multirow{2}{*}{\multicolumn{2}{|c|}{ Total }} \\
\hline & \multicolumn{2}{|c|}{$\begin{array}{l}\text { Arih } \\
\text { Ersada } \\
\text { (Karo) }\end{array}$} & \multicolumn{2}{|c|}{$\begin{array}{c}\text { Buluh Duri } \\
\text { Mandiri } \\
\text { (Serdang } \\
\text { Bedagai) } \\
\end{array}$} & \multicolumn{2}{|c|}{$\begin{array}{l}\text { Subur } \\
\text { Makmur } \\
\text { (Asahan) }\end{array}$} & & \\
\hline & $\mathrm{F}$ & $\%$ & $\mathrm{~F}$ & $\%$ & $\mathrm{~F}$ & $\%$ & $\mathrm{~F}$ & $\%$ \\
\hline $\begin{array}{l}\text { Strongly } \\
\text { Disagree }\end{array}$ & 8 & 2,7 & 0 & 0,0 & 0 & 0,0 & 8 & 2,7 \\
\hline $\begin{array}{l}\text { Don't } \\
\text { Agree }\end{array}$ & 68 & 22,7 & 5 & 1,7 & 19 & 6,3 & 92 & 30,7 \\
\hline Agree & 22 & 7,3 & 73 & 24,3 & 70 & 23,3 & 165 & 55 \\
\hline $\begin{array}{l}\text { Strongly } \\
\text { Agree }\end{array}$ & 2 & 0,7 & 22 & 7,3 & 11 & 3,7 & 35 & 11,7 \\
\hline Total & 100 & 33,3 & 100 & 33,3 & 100 & 33,3 & 300 & 100 \\
\hline
\end{tabular}

Source: Research data has been processed, 2021

Table 4.1 shows that the majority of respondents $(66.7 \%)$ agree and strongly agree that VBC managers have utilized village potential in developing business units. This finding illustrates that VBC managers in developing business units have utilized village potential optimally, although there are still respondents (33.3\%) who disagree and strongly disagree that VBC managers have optimally utilized village potential in developing business units. The results of interviews with informants also show that the business activities that have been 
carried out by VBC are generally based on the potential and needs of the village. Even the future VBC development plan is still based on the potential of the village. The results of an interview with one of the informants stated:

"The future program plan or next business is that we want to open the development of a tourism business unit. Because we have the natural potential to develop this business. The tourism we design is educational tourism, where school children can later learn about agriculture in this village."

In addition to utilizing village potential from natural resources, VBC also utilizes the potential of human resources in the village, especially youth human resources (millennials). VBC Buluh Duri Mandiri (Buduma), for example, has recruited young people to be involved in the Rafting and Digital Marketing business unit. These young people have the ability in terms of information technology and they are also quickly skilled in guiding consumers who will go on rafting tours. VBC Arih Ersada has also taken advantage of the potential of young people in the use of information technology (social media) to market their business units, especially those related to tourism marketing (flower agrotourism) to potential tourists. The use of information technology in marketing VBC products should be carried out by all existing VBC, because Indonesian people who use the internet are very large and continue to increase from year to year. Based on data reported by Kominfo [8] that Indonesian internet users 2019-2020 experienced an increase of 73.7 percent, up from 64.8 percent in 2018 . Indonesia in 2019 numbered 266,911,900 million, so that Indonesian internet users are estimated to be 196.7 million users. Internet users in Indonesia continued to increase in the following year. In January 2021, there were 202.6 million internet users in Indonesia. The number of internet users in Indonesia has increased by 27 million people or an increase of $16 \%$, and Youtube is the social media most accessed by internet users, followed by Facebook and Instagram [9]. This is certainly an opportunity for VBC to be able to maximize technological advances in the development of business units. Technological advancements have also been utilized by the manager of the VBC Buluh Duri Mandiri by forming a digital marketing team.

In addition to developing village potential in the formation of $\mathrm{VBC}$, VBC managers also form and develop business units in accordance with the wishes and needs of the local village community. This can be seen in Table 4.2.
Tabel 4.2. Business Units Developed by VBC in accordance with the wishes of the community

\begin{tabular}{|l|c|c|c|c|c|c|c|c|}
\hline \multirow{4}{*}{} & \multicolumn{7}{|c|}{ VBC } & \multicolumn{2}{|c|}{} \\
\cline { 2 - 9 } & $\begin{array}{c}\text { Arih } \\
\text { Ersada } \\
\text { (Karo) }\end{array}$ & $\begin{array}{c}\text { Buluh Duri } \\
\text { Mandiri } \\
\text { (Serdang } \\
\text { Bedagai) }\end{array}$ & $\begin{array}{c}\text { Subur } \\
\text { Makmur } \\
\text { (Asahan) }\end{array}$ & \multicolumn{2}{|c|}{ Total } \\
\cline { 2 - 9 } & $\mathrm{F}$ & $\%$ & $\mathrm{~F}$ & $\%$ & $\mathrm{~F}$ & $\%$ & $\mathrm{~F}$ & $\%$ \\
\hline $\begin{array}{l}\text { Strongly } \\
\text { Disagree }\end{array}$ & 4 & 1,3 & 0 & 0,0 & 1 & 0,3 & 5 & 1,7 \\
\hline $\begin{array}{l}\text { Don't } \\
\text { Agree }\end{array}$ & 76 & 25,3 & 13 & 4,3 & 16 & 5,3 & 105 & 35,0 \\
\hline Agree & 7 & 2,3 & 54 & 18,0 & & 23,0 & 130 & 43,3 \\
\hline $\begin{array}{l}\text { Strongly } \\
\text { Agree }\end{array}$ & 13 & 4,3 & 33 & 11,0 & 14 & 4,7 & 60 & 20,0 \\
\hline Total & 100 & 33,3 & 100 & 33,3 & 100 & 33,3 & 300 & 100 \\
\hline
\end{tabular}

Source: Research data has been processed, 2021

Table 4.2. shows that the majority of respondents $(63.3 \%)$ gave answers agreeing and strongly agreeing that VBC managers have developed business units in accordance with the wishes and needs of the community, and a small proportion of respondents $(36.7 \%)$ gave answers disagree and strongly disagree. This finding indicates that the manager in establishing the VBC business unit has been in accordance with the wishes of the village community. The business units carried out by VBC are the needs of the local community. The provision of clean water by VBC Buduma and VBC Subur, for example, is very much needed by residents who have had difficulties in getting clean water. Although in terms of profit, this clean water supply business does not provide financial benefits for VBC, but from the point of view of the need for public services, the existence of this clean water business unit has improved the quality of service for villagers. As stated by one of the VBC managers:

\begin{abstract}
"This clean water supply business does not provide much economic benefit for VBC, because the tariffs made by VBC are also not expensive, so all residents are able to pay for it. But the benefits felt by residents are enormous. So, our business unit is not only pursuing financial gain but also how to fulfill the basic needs of the community properly. The purpose of VBC is not only to gain economic benefits, but also to improve the quality of public services.
\end{abstract}

The ability of managers to develop VBC based on the potential and needs of rural communities will have an impact on increasing community participation in VBC activities and businesses. As stated by Soleh [10], the local potential of the village is the power, strength, ability, and ability possessed by a village that has the possibility to be developed in order to improve the welfare of the community. The success and progress of 
VBC is highly dependent on the ability of VBC managers to see and utilize this potential. According to Soetomo [11], at least 3 things are needed in identifying the local potential of the village, namely: 1) Identifying community needs which from time to time always experience developments and changes in line with community changes and developments; 2) Identification of potentials, resources and opportunities that also continue to grow; and 3) Processes and efforts to find more profitable ways to utilize existing potential and resources.

The dynamics and development of VBC so that they are able to achieve their goals in village development to improve community welfare cannot be separated from the ability of VBC managers to synergize the components of the village community, including the village government in exploring the local potential of the village. The better the synergy of VBC with the village components, the more the local potentials of the village will be explored and will be more utilized for the welfare of the village community.

\section{CONCLUSION}

From the results of the research as described in the previous section, several conclusions can be drawn, including: first, the three VBC studied in general have utilized the local potential of the village in an effort to develop the VBC business unit, but the ability of managers to utilize the local potential of the village has not been evenly distributed for the three VBC. Second, the synergy of $\mathrm{VBC}$ with various elements of the village community is one of the determining factors to be able to explore and utilize the local potential of the village for the development of VBC.

\section{ACKNOWLEDMENTS}

The authors gratefully acknowledge that the present research is supported by Kemristek-BRIN and Universitas Sumatera Utara of Year 2021.

\section{REFERENCES}

[1] Badaruddin, Kariono, Ermansyah, Lina Sudarwati, Community Empowerment Based Social Capital and Village Business Company (BUMDes), Proceedings of the 2ndInternational Conference on Social and Political Development (ICOSOP 2017), Advances in Social Sciance, Education and Humanities Research (ASSEHR), Volume 136, Atlantis Press, 2017, https://www.atlantispress.com/proceedings/icosop-17/25892080

[2] Badaruddin, Erika Revida, Ermansyah, and Iskandar Muda, Village Governance with Implementation of Law Number 6 of 2014 on the Village and Village Administration, International Journal of Economic Research, Serials Publications Pvt. Ltd, Vol. 14, No.17, 2017

[3] https://www.researchgate.net/publication/3224921 66_Village_governance_with_implem
[4] entat

ion_of_law_number_6_of_2014_on_the_village_a nd_village_administration

[5] Soetomo, Keswadayaan Masyarakat Manifestasi Kapasitas Masyarakat Untuk Berkembang Secara Mandiri, Pustaka Pelajar, Yogyakarta, 2014

[6] Danaresa, W., dan Herawati, N.R., Strategi Pengembangan Badan Usaha Milik Desa Tirta Mandiri Ponggok Desa Ponggok Kabupaten Klaten Jawa Tengah, Journal of Politic and Government Studies, 2018, 7 (1), pp. 191-120

[7] Badaruddin Badaruddin, Kariono Kariono, Ermansyah Ermansyah \& Lina Sudarwati, Village community empowerment through village owned enterprise based on social capital in North Sumatera, Asia Pacific Journal of Social Work and Development, 2020, pp. 1-13, DOI: $10.1080 / 02185385.2020 .1765855$

[8] Kurniasih, D., Setyo, P.I. dan Wijaya, S.S., Faktor Penentu Keberhasilan Implementasi Strategi Pengembangan Badan Usaha Milik Desa di Kabupaten Banyumas, Jurnal Ilmiah Wahana Bhakti Praja, 9(2), pp. 134-143, 2019

[9] Iyan, Asriansyah S. Mawung, dan Bambang Mantikei, Strategi Pengembangan Badan Usaha Milik Desa (BUMDes) Sumber Mulia di Desa Purwareja Kabupaten Lamandau, Journal of Environment and Management, 1(2), pp. 103-111, 2020

[10] Kementerian Komunikasi dan Informatika Republik Indonesia, Dirjen PPI: Survei Penetrasi Pengguna Internet di Indonesia Bagian Penting dari Transformasi Digital, 2020, https://www.kominfo.go.id/dirjen-ppi-surveipenetrasi-pengguna-internet-di-indonesia-bagianpenting-dari-transformasi-digital/0/berita_satker

[11] Data Reportal, Digital 2021: Indonesia, 2021, https://datareportal.com/reports/digital-2021indonesia

[12] Soleh, Ahmad, Strategi Pengembangan Desa, Jurnal Sungkai, 5(1), Hal. 32-52, 2017

[13] Soetomo, Keswadayaan Masyarakat Manifestasi Kapasitas Masyarakat Untuk

[14] Berkembang Secara Mandiri, Pustaka Pelajar, Yogyakarta, 2014 